\title{
IL-1 $\beta$ augments TGF- $\beta$ inducing epithelial-mesenchymal transition of epithelial cells and associates with poor pulmonary function improvement in neutrophilic asthmatics
}

Shengding Zhang ${ }^{2,3+}$, Yu Fan ${ }^{4 \dagger}$, Lu Qin ${ }^{2,3}$, Xiaoyu Fang ${ }^{2,3}$, Cong Zhang ${ }^{2,3}$, Junqing Yue 2,3, Wenxue Bai ${ }^{2,3}$, Gang Wang ${ }^{5}$, Zhihong Chen ${ }^{6}$, Harld Renz ${ }^{7,8}$, Chrysanthi Skevaki ${ }^{7,8}$, Xiansheng Liu ${ }^{1,2,3^{*}}$ and Min Xie ${ }^{1,2,3^{*}}$ (1)

\begin{abstract}
Background: Neutrophilic asthmatics (NA) have less response to inhaled corticosteroids. We aimed to find out the predictor of treatment response in NA.

Methods: Asthmatics $(n=115)$ and healthy controls $(n=28)$ underwent clinical assessment during 6 -month followup with standardized therapy. Asthmatics were categorized by sputum differential cell count. The mRNA expressions were measured by RT-qPCR for sputum cytokines (IFN- $\gamma$, IL-1 $\beta, I L-27, F O X P 3, I L-17 A$, and IL-5). The protein of IL-1 $\beta$ in sputum supernatant was detected by ELISA. Reticular basement membranes (RBM) were measured in the biopsy samples. The role and signaling pathways of IL-1 $\beta$ mediating the epithelial-mesenchymal transition (EMT) process were explored through A549 cells.
\end{abstract}

Results: NA had increased baseline sputum cell IL-1 $\beta$ expression compared to eosinophilic asthmatics (EA). After follow-up, NA had less improvement in FEV 1 compared to EA. For all asthmatics, sputum IL-1 $\beta$ mRNA was positively correlated with protein expression. Sputum IL-1 $\beta$ mRNA and protein levels were negatively correlated to FEV improvement. After subgrouping, the correlation between IL-1 $\beta$ mRNA and FEV improvement was significant in NA but not in EA. Thickness of RBM in asthmatics was greater than that of healthy controls and positively correlated with neutrophil percentage in bronchoalveolar lavage fluid. In vitro experiments, the process of IL-1 $\beta$ augmenting TGF- $\beta 1$ induced EMT cannot be abrogated by glucocorticoid or montelukast sodium, but can be reversed by MAPK inhibitors.

Conclusions: $I L-1 \beta$ level in baseline sputum predicts the poor lung function improvement in NA. The potential mechanism may be related to IL-1 $\beta$ augmenting TGF- $\beta 1$-induced steroid-resistant EMT through MAPK signaling pathways.

\footnotetext{
*Correspondence: doctorliu69@126.com; xie_m@126.com

†Shengding Zhang and Yu Fan contributed equally as co-first authors

1 Department of Respiratory and Critical Care Medicine, Shanxi Bethune

Hospital, Shanxi Academy of Medical Sciences, Tongji Shanxi Hospital,

Third Hospital of Shanxi Medical University, Taiyuan 030032, China

Full list of author information is available at the end of the article
} permits use, sharing, adaptation, distribution and reproduction in any medium or format, as long as you give appropriate credit to the original author(s) and the source, provide a link to the Creative Commons licence, and indicate if changes were made. The images or other third party material in this article are included in the article's Creative Commons licence, unless indicated otherwise in a credit line to the material. If material is not included in the article's Creative Commons licence and your intended use is not permitted by statutory regulation or exceeds the permitted use, you will need to obtain permission directly from the copyright holder. To view a copy of this licence, visit http://creativecommons.org/licenses/by/4.0/. The Creative Commons Public Domain Dedication waiver (http://creativeco mmons.org/publicdomain/zero/1.0/) applies to the data made available in this article, unless otherwise stated in a credit line to the data. 
Trial registration: This study was approved by the Ethics Committee of Tongji Hospital, Tongji Medical College, Huazhong University of Science and Technology (IRB ID: 20150406).

Keywords: Asthma, Epithelial-mesenchymal transition, IL-1 $\beta$, Pulmonary function, TGF- $\beta 1$

\section{Background}

Asthma is a heterogeneous respiratory disease involving with airway inflammation and hyperresponsiveness. Although eosinophil cell count could be a very good marker to predict therapy response in type- 2 asthma, it is not clear which innate biomarkers could predict the poor improvement in non-type- 2 asthma patients. Interleukin (IL)-1 $1 \beta$ is a typical innate immune cytokine which can be mediated by inflammasomes [1]. A recent study shows both leucine-rich repeat-containing family protein 3 inflammasome activation and IL- $1 \beta$ gene expression increase in neutrophilic asthma [2].

Respiratory symptoms and lung function tests are very important for asthma patient evaluation. According to GINA2020, lung function should be evaluated regularly for asthma patients [3]. Low forced expiratory volume in one second $\left(\mathrm{FEV}_{1}\right)$ is a strong independent predictor for acute exacerbations $[4,5]$ and lung function decline [6]. Since the correlation between lung function and symptoms is weak, it is suggested to monitor lung function in addition to symptoms when evaluating the efficiency of asthma therapy [7].

Airway remodeling has been implicated in persistent airflow obstruction, irreversible decline of lung function, and increased airway hyper-responsiveness in asthma [8]. Airway remodeling is considered the result of repetitive injury caused by chronic airway inflammation. However, the relation between chronic airway inflammation and airway remodeling remains unclear. Epithelial-mesenchymal transition (EMT), a dynamic process by which epithelial cells lose their original epithelial phenotype and transformed into cells with a mesenchymal phenotype, has been demonstrated to play an essential role in airway remodeling. Previous studies have shown that a variety of inflammatory factors, including innate immune cytokine and type 2 cytokines, are involved in EMT [9], that may contribute to airway remodeling and then leads to poor asthma control.

To investigate the values of typical innate immune biomarkers and type-2 biomarkers in predicting the response to asthma therapy and the potential mechanisms, we conducted a prospective study. Our results indicated that IL- $1 \beta$ level in induced sputum of untreated patients predicts the poor lung function improvement in neutrophilic asthmatics. The potential mechanism is related to IL- $1 \beta$ augmenting TGF- $\beta 1$ induced EMT.

\section{Methods}

Subjects and study design

Adults patients with physician diagnosed asthma, according to the Global Initiative for Asthma 2014, were recruited if they met the following key criteria: bronchoprovocation test with methacholine PD $20<2.505 \mathrm{mg}$ or bronchodilation $\mathrm{FEV}_{1}$ change $>200 \mathrm{ml}$ and $12 \%$; not received treatment with any inhaled or systemic glucocorticoids in the previous three months; and successfully induced sputum at baseline during June 15, 2015-April 20, 2017 from the Department of Respiratory and Critical Care Medicine at Tongji Hospital (Wuhan, China) of Huazhong University of Science and Technology. The exclusion criteria included: acute episode in recent one month; respiratory infection in the last two weeks; comorbid with chronic obstructive pulmonary disease; bronchiectasis; other respiratory disease; pregnancy; or serious organ failure. Nonsmokers were defined as never smokers or ex-smokers who had the smoking history of less than five pack-years and quit smoking for longer than six months, otherwise defined as smokers. Atopy was defined as at least one specific $\operatorname{IgE}(\geq 0.35 \mathrm{kUI} / \mathrm{L})$ toward common aeroallergens, a positive skin prick test response, or both. Healthy controls had no history of chronic respiratory disease; no respiratory infection within two weeks; no history of atopy; no family history of asthma; no smoke; no severe systemic disease.

Participants at the baseline visit (labeled as visit 1, V1) underwent clinical characteristics assessment, spirometry and sputum induction. In the follow-up, only those received 6-month standardized therapy with good adherence were recorded ACT score and pulmonary function test at the end of 6-month treatment (labeled as visit 2, V2). The improvement of $\mathrm{FEV}_{1}$ was calculated in three ways [10]: (1) absolute change in $\mathrm{FEV}_{1}$, calculated by the difference between $\mathrm{FEV}_{1}$ after six months treatment and baseline $\mathrm{FEV}_{1}$, labeled as $\triangle \mathrm{FEV}_{1(\mathrm{~V} 2-\mathrm{V} 1)}$; (2) $\mathrm{FEV}_{1}$ change ratio, calculated by absolute change in $\mathrm{FEV}_{1}$ divided by baseline $\mathrm{FEV}_{1}$, labeled as $\Delta \mathrm{FEV}_{1(\mathrm{~V} 2-\mathrm{V} 1)} / \mathrm{FEV}_{1(\mathrm{~V} 1)}$ baseline; (3) absolute change in percentage of the predicted $\mathrm{FEV}_{1}$, calculated by the difference between percentage of the predicted $\mathrm{FEV}_{1}$ after six months treatment and baseline, labeled as $\triangle \mathrm{FEV}_{1} \%_{(\mathrm{V} 2-\mathrm{V} 1)}$.

All participants were given a written informed consent prior to clinical data and sample collection. The study was approved by the Ethics Committee of Tongji 
Hospital, Tongji Medical College, Huazhong University of Science and Technology (IRB ID: 20150406).

\section{Sputum induction}

Sputum induction was processed and cytospins were prepared as described before [11]. Using sputum eosinophils and neutrophils count, participants were categorized as eosinophilic (eosinophils $\geq 3 \%$ and neutrophils $<61 \%$ ), neutrophilic (neutrophils $\geq 61 \%$ and eosinophils $<3 \%$ ), mixed-granulocytic (neutrophils $\geq 61 \%$ and eosinophils $\geq 3 \%$ ) or pauci-granulocytic asthma (sputum neutrophils $<61 \%$ and sputum eosinophils $<3 \%$ ) [2]. Sputum samples with enough cells for mRNA isolation and less than $3 \%$ epithelial cells were processed for gene expression using quantitative reverse transcription (RT-qPCR), sputum supernatant was measured for IL- $1 \beta$ concentration with enzyme-linked immunosorbent assay (ELISA) as previously described [12].

\section{RT-qPCR and ELISA}

Total RNA was extracted from the cell pellets if they were enough. Reverse transcription was performed using the PrimeScript RT reagent Kit (Takara, Dalian, China). The specific PCR primers were synthesized by Riobio Co. Lit. (Guangzhou, China). RT-qPCR assays were performed using the SYBR PremxiExTag (Takara, Dalian, China) on a 7500 RT-qPCR System (Life Technologies, Carlsbad, $\mathrm{CA}$ ). The relative expression levels were normalized to $\beta$-actin and calculated using the $2^{-\Delta \mathrm{CT}}$ method.

Sputum supernatant was store in at $-80{ }^{\circ} \mathrm{C}$ for subsequent detection. IL-1 $\beta$ in sputum supernatant was measured by Human IL-1beta DuoSet ELISA Kit (R\&D Systems Inc. MN, USA) according to the manufacturer's instruction. The detection limits were $3.91 \mathrm{pg} / \mathrm{mL}$. All values below the detection limits were set as $3.91 \mathrm{pg} / \mathrm{mL}$.

\section{Bronchoscopy and endobronchial biopsy}

Bronchial alveolar lavage cells were obtained bronchoscopically from fourth- to fifth-generation airways of the right middle lobe. Endobronchial biopsy was taken from R8-R9 ridge of the right lower lobe subsegments and fixed in $4 \%$ formalin for further hematoxylin-eosin staining, as previously described [13].

\section{Measurement of the thickness of reticular basement membrane}

The section of each endobronchial biopsy was taken $2-5$ micrographs for the best preserved mucous membrane and reticular basement membrane (RBM) under microscope with Qian Ping image system. The thickness of RBM was calculated by dividing the area by the length of RBM using an image analysis system (Image Plus Pro), as previously described [13].

\section{Cell culture and cytokine stimulation}

The A549 cells were grown in DMEM (HyClone, CT, USA) supplemented with $10 \%$ fetal bovine serum (Gibco, Australia). The cells would be put in DMEM medium with $1 \%$ low concentration fetal bovine serum for $24 \mathrm{~h}$ before the cytokines stimulation. $10 \mathrm{ng} / \mathrm{ml} \mathrm{IL-4,} 5 \mathrm{ng} /$ $\mathrm{ml}$ transforming growth factor (TGF)- $\beta 1$, and $10 \mathrm{ng} / \mathrm{ml}$ IL-1 $\beta$ (PeproTech, Princeton, USA) were used separately or in combination to stimulate the cells. The stimulation would last for $24 \mathrm{~h}$ to observe morphological change of A549 cells or detect mRNA expression of EMT markers, or $48 \mathrm{~h}$ to detect protein expression EMT markers, or for $1 \mathrm{~h}$ to detect the phosphate kinase expression. Before the cytokines stimulation, cells were pretreated for $1 \mathrm{~h}$ with MEK inhibitor U0126, p-JNK1/2 inhibitor SP600125, or p38 inhibitor SB203580 (10 $\mu$ M, MCE, Shanghai, China) if necessary. To detect the effect of glucocorticoid and montelukast sodium on TGF- $\beta 1$ combined with IL-1 $\beta$ induced EMT in A549 cells, methylprednisolone (Sigma, USA) or montelukast sodium (Merck, NJ, USA) were dissolved in phosphate buffer saline, then cells were pretreated for $24 \mathrm{~h}$ with methylprednisolone $(0.5 \mathrm{mg} / \mathrm{ml})$ or montelukast sodium $(0.01 \mu \mathrm{M})$ followed by TGF- $\beta 1$ combine with IL- $1 \beta$ stimulation.

\section{Western blot}

RIPA lysis buffer (Aspenbio, Wuhan, China) was used to extract total cellular protein. The primary antibodies including E-cadherin, Fibronectin (1:2000 dilution, Proteintech, Wuhan, China), p-ERK1/2, p-JNK, p-p38, p-AKT, p-NF kB, and p-smad3 (1:1000 dilution, Cell Signaling Technology, Danvers, MA, USA) were incubated in $4^{\circ} \mathrm{C}$ overnight. Goat anti-rabbit IgG and Goat anti-mouse IgG (1:4000 dilution, Aspenbio, Wuhan, China) were used as secondary antibodies. The protein expression levels were normalized to GAPDH or $\beta$-actin (1:2000, Sungenebiotech, Tianjin, China).

\section{Statistical analyses}

Data were expressed as means \pm standard deviation or medians with interquartile range. Sputum gene expression levels were log-transformed. Parametric continuous variables were tested by Student's t-test. Multiple groups were compared using one-way analysis of variance with a Bonferroni correction (normal data) or a Kruskal-Wallis test with a Dunn intergroup comparison (non-normal data). Categorical variables were analyzed using ChiSquare or Fisher exact test. Spearman's rank correlation coefficient was used for correlation analyses. $P<0.05$ was considered statistically significant. SPSS software V.20.0 was used for analyses. 
Table 1 Baseline demographic characteristics of all groups $(n=143)$

\begin{tabular}{|c|c|c|c|c|c|c|}
\hline & \multirow[b]{2}{*}{ Healthy $(n=28)$} & \multicolumn{4}{|l|}{ Asthmatic patients } & \multirow[b]{2}{*}{ Overall $P$ value } \\
\hline & & Eosinophilic $(n=32)$ & Neutrophilic $(n=30)$ & Mixed $(n=11)$ & $\begin{array}{l}\text { Paucigranulocytic } \\
(\mathrm{n}=42)\end{array}$ & \\
\hline Age (y) & $25(23-26)$ & $44(27-50)^{5}$ & $43(34-51)^{5}$ & $49(41-51)^{\S}$ & $46(31-52)^{5}$ & $<0.001$ \\
\hline Male sex n. (\%) & $14(50)$ & $20(63)$ & $9(30)$ & $8(73)$ & $17(41)$ & 0.035 \\
\hline $\mathrm{BMI}\left(\mathrm{kg} / \mathrm{m}^{2}\right)$ & $20.3(18.9-23.5)$ & $22.5(20.7-24.6)$ & $22.3(20.3-23.4)$ & $23.7(22.3-27.2)$ & $22.4(18.7-25.6)$ & 0.152 \\
\hline Smoker n. (\%) & $0(0)$ & $10(31)^{5}$ & $5(17)^{\S}$ & $3(27)^{5}$ & $13(31)^{5}$ & 0.016 \\
\hline Atopy n. (\%) & $0(0)$ & $18(56)^{5}+$ & $9(30)^{5}$ & $4(36)^{5}$ & $16(38)^{\S}$ & $<0.001$ \\
\hline Asthma course (y) & NA & $2.0(1.0-7.5)$ & $2.8(1.0-8.0)$ & $4.0(2.0-11.0)$ & $1.0(0.25-7.0)$ & 0.121 \\
\hline Blood eosinophils (\%) & $1.8(1.3-2.7)$ & $6.4(3.3-8.8)^{5 \dagger} £$ & $2.6(0.9-4.6)$ & $5.5(2.4-7.9)^{\S} £$ & $2.1(1.2-3.2)$ & $<0.001$ \\
\hline Blood neutrophils (\%) & $56.7(53.7-61.5)$ & $54.6(49.2-61.7)$ & $61.2(53.6-65.6)$ & $59.7(55.6-66.1)$ & $56.3(52.7-63.3)$ & 0.356 \\
\hline $\mathrm{FEV}_{1}(\mathrm{~L})$ & $3.35 \pm 0.55$ & $2.55 \pm 0.64^{\S}$ & $2.59 \pm 0.79^{\S}$ & $2.66 \pm 0.86$ & $2.64 \pm 0.59 \S$ & $<0.001$ \\
\hline $\mathrm{FEV}_{1}(\%)$ & $90.9 \pm 7.2$ & $82.8 \pm 17.1$ & $90.1 \pm 18.2$ & $83.7 \pm 19.3$ & $90.1 \pm 13.2$ & 0.163 \\
\hline $\mathrm{FEV}_{1} / \mathrm{FVC}(\%)$ & $87.3 \pm 6.1$ & $67.0 \pm 8.9 \S$ & $71.9 \pm 11.8 \S$ & $64.3 \pm 9.7 \S$ & $73.2 \pm 10.1 \S$ & $<0.001$ \\
\hline Serum lgE (IU/ml) & $40(12-66)$ & $215(60-519)^{5 \pm}$ & $92(36-254)$ & $118(78-410)$ & $52(14-193)$ & $<0.001$ \\
\hline $\mathrm{FE}_{\mathrm{NO}}(\mathrm{ppb})$ & NA & $86(30-112)^{\dagger £}$ & $27(17-45)$ & $48(31-85)^{£}$ & $23(11-33)$ & $<0.001$ \\
\hline ACT score & NA & $16.0(14-18)^{f}$ & $16.5(13-19)$ & $16.0(14-19)$ & $18.0(16-19)$ & 0.038 \\
\hline \multicolumn{7}{|c|}{ Induced sputum characteristics ${ }^{\ddagger}$} \\
\hline Macrophages (\%) & $37.3(28.1-50.2)$ & $22.1(11.5-35.8)^{£}$ & $8.9(4.3-18.2)^{5} \mathrm{k}^{£}$ & $4.6(3.4-9.4)^{\S k f}$ & $47.7(37.1-58.4)$ & $<0.001$ \\
\hline Neutrophils (\%) & $51.3(43.2-64.7)$ & $31.7(18.3-45.7)^{\S+๘}$ & $81.7(68.6-89.6) \S^{\ddagger}$ & $74.1(64.6-84.9)^{£}$ & $39.1(30.3-46.0)$ & $<0.001$ \\
\hline Eosinophils (\%) & $0.1(0-0.2)$ & $21.1(7.7-43.1)^{\S+£}$ & $0.5(0.1-1.6)$ & $8.1(5.0-15.1)^{\S+£}$ & $0.2(0-0.9)$ & $<0.001$ \\
\hline Lymphocytes (\%) & $4.1(2.6-6.8)^{\mathrm{kf}}$ & $8.1(5.0-13.7)$ & $4.7(3.1-10.7)$ & $4.6(2.7-10.1)$ & $7.8(5.5-13.8)$ & 0.002 \\
\hline
\end{tabular}

Normal data are expressed as mean \pm SD and non-normal data are described as median (IQR). Multiple groups were compared using one-way analysis of variance (ANOVA) with a Bonferroni correction (normal data) or a Kruskal-Wallis test with a Dunn intergroup comparison (non-normal data). The Levene method was used to test for multiple-sample homogeneity of variance, and Welch method was performed when data are heterogeneous. The $x^{2}$ or Fisher exact tests were used to compare ratios;

$B M I$ body mass index, $F E_{N O}$ fraction of exhaled nitric oxide, $A C T$ Asthma Control Test, IQR interquartile range, NA not available

Atopy was defined aswas defined as at least one specific $\lg \mathrm{E}(\geq 0.35 \mathrm{kUI} / \mathrm{L}$ ) toward common aeroallergens, a positive skin prick test response, or both Smoker was defined as current smokers or ex-smokers who had the smoking history of more than 5 pack-years or quit smoking for less than 6 months

${ }^{\ddagger}$ Data were missing for five patients in healthy group

${ }^{\S} p<0.05$ versus healthy subjects

${ }^{k} p<0.05$ versus patients with eosinophilic asthma

${ }^{+} p<0.05$ versus patients with neutrophilic asthma

" $p<0.05$ versus patients with mixed asthma

${ }^{\mathrm{f}} p<0.05$ versus patients with Paucigranulocytic asthma

\section{Results}

\section{Subjects characteristics}

Baseline characteristics of the subjects were summarized in Table 1. 28 healthy controls and 115 asthmatics were enrolled with induced sputum samples. Identified by sputum differential cell counts, asthmatic patients were subgrouped into eosinophilic $(n=32)$, neutrophilic $(n=30)$, mixed $(n=11)$ and pauci-granulocytic $(n=42)$ asthmatics. Although healthy controls were younger than asthmatic patients, the differences of age, sex, body mass index (BMI), smoking status, and baseline lung function among the four asthmatic subgroups were not significant. The eosinophilic group was presented with higher levels of blood eosinophil counts, higher exhaled NO and higher levels of total IgE than the neutrophilic group at the baseline visit. More details were also summarized in Table 1.

\section{Sputum profile of asthmatic patients}

The eosinophilic group had higher baseline sputum cell IL-5 mRNA expression compared to neutrophilic $(p=0.004)$ and pauci-granulocytic groups $(p<0.001)$ (Additional file 1: Figure S1b). Mixed-granulocytic group had higher baseline sputum cell IL-17A mRNA expression compared to neutrophilic $(p=0.005)$ and pauci-granulocytic groups $(p=0.020) \quad$ (Additional file 1: Figure S1d). Neutrophilic group had higher baseline sputum cell IL-1 $\beta$ mRNA expression compared to eosinophilic $(p<0.0001)$ and pauci-granulocytic groups $(p=0.024)$ (Fig. 1a). Neutrophilic group had higher levels of IL- $1 \beta$ protein in sputum supernatant than healthy 

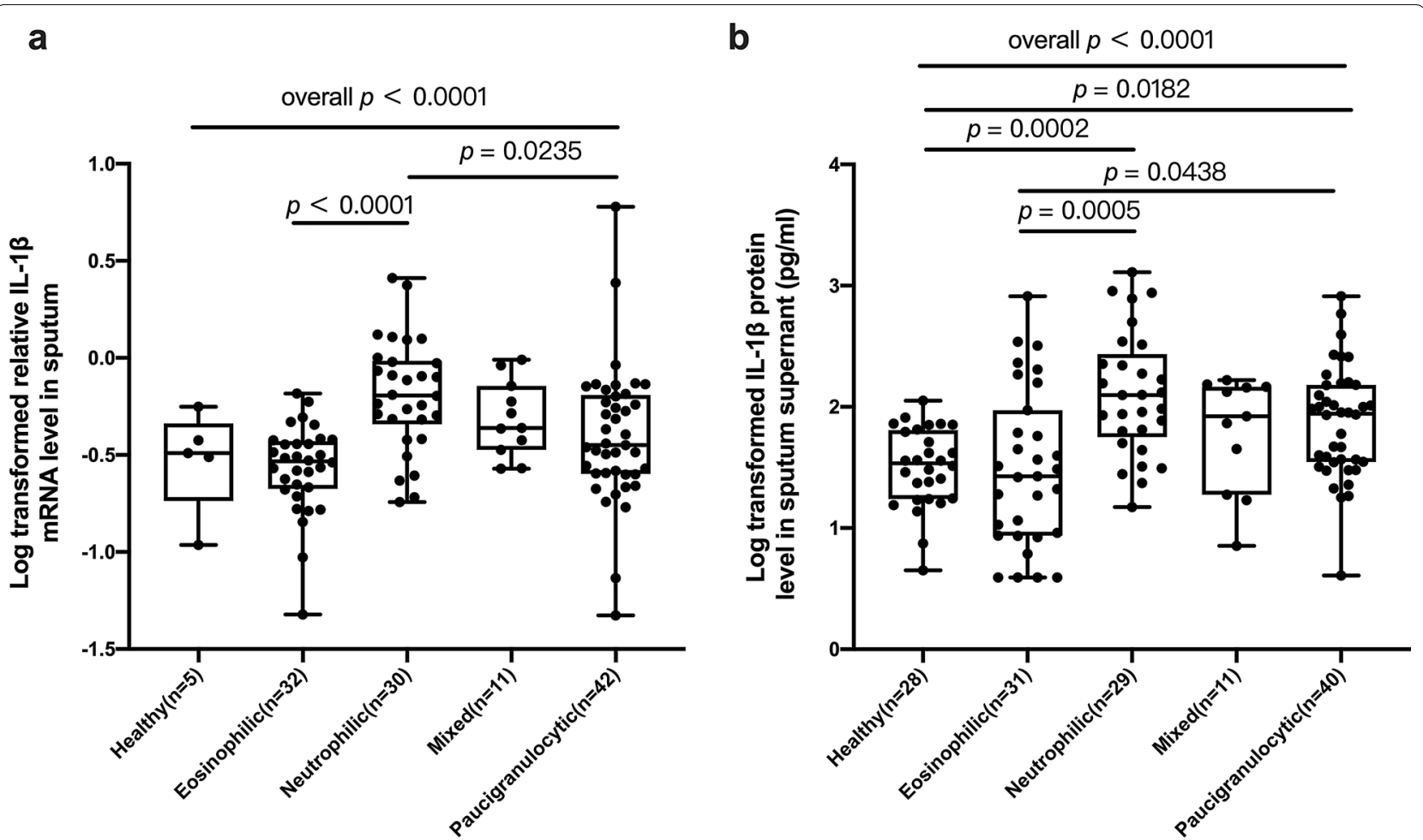

Fig. 1 The baseline $\mathbf{a}$ sputum cell IL-1 $\beta$ mRNA levels and $\mathbf{b} \mathrm{IL}-1 \beta$ protein levels in sputum supernatant among healthy controls and four subgroups of asthmatic patients. The data are presented as dot plots, mRNA and protein expression were log transformed

controls $(p<0.001)$ and eosinophilic groups $(p<0.001)$. There was no significant difference of the baseline mRNA level of sputum IFN- $\gamma$, IL-27 or FOXP3 mRNA expression among the four subgroups (Additional file 1: Figure S1a, b, and e).

As is shown in Additional file 2: Table S1, IL-1 $\beta$ mRNA expression was positively correlated with neutrophil percentage $(\mathrm{R}=0.459, p<0.0001)$, but negatively correlated with eosinophil percentage $(\mathrm{R}=-0.224$, $p=0.017)$ and macrophage percentage $(\mathrm{R}=-0.230$, $p=0.014)$. IL-27 mRNA expression was positively correlated with IFN- $\gamma(\mathrm{R}=0.658, p<0.0001)$ and IL-5 mRNA expression $(\mathrm{R}=0.442, p<0.0001)$. IFN- $\gamma$ mRNA expression was positively correlated with IL-5 mRNA expression $(\mathrm{R}=0.564, p<0.0001)$. Eosinophil percentage was positively correlated with IL- 5 mRNA expression $(\mathrm{R}=0.370, p<0.0001)$, but negatively correlated with neutrophil percentage $(\mathrm{R}=-0.196, p=0.035)$ and macrophage percentage $(\mathrm{R}=-0.270, p=0.003)$.

\section{Poor pulmonary function improvement in neutrophil asthmatic patients}

54 patients were followed up for six months with standardized asthma therapy. Baseline demographic characteristics of these patients are summarized in Additional file 3: Table S2. There was no significant difference in age, sex, BMI, smoking status, or baseline lung function among the four asthmatic groups.

The neutrophilic asthmatics had less improvement in $\mathrm{FEV}_{1}$ as compared with eosinophilic asthmatics (Fig. 2ac). Mixed-granulocytic and pauci-granulocytic asthmatics had less improvement in ACT scores as compared with eosinophilic asthmatics (Fig. 2d). There was no significant difference in post-treatment $\mathrm{FEV}_{1}$ levels or ACT scores among four asthmatic groups (Additional file 4: Figure S2).

For all asthmatic patients $(n=54)$, baseline sputum IL-1 $\beta$ mRNA was negatively correlated with absolute change in $\operatorname{FEV}_{1}(\mathrm{R}=-0.316, p=0.020)$, absolute change in percentage of the predicted $\mathrm{FEV}_{1}(\mathrm{R}=-0.339$, $p=0.012)$, and $\mathrm{FEV}_{1}$ change ratio $(\mathrm{R}=-0.282, p=0.039)$ (Fig. $3 \mathrm{a}-\mathrm{c}$ ). Baseline sputum IL-1 $\beta$ mRNA was positively correlated with baseline sputum IL- $1 \beta$ protein expression $(\mathrm{R}=0.363, p=0.008)$. Baseline sputum IL-1 $\beta$ protein expression was negatively correlated with absolute change in percentage of the predicted $\mathrm{FEV}_{1}(\mathrm{R}=-0.271$, $p=0.049$ ) (Fig. 3e), but had no significant correlation with absolute change in $\mathrm{FEV}_{1}$ and $\mathrm{FEV}_{1}$ change ratio (Fig. 3d and f). Eosinophil percentage was positively correlated with absolute change in $\mathrm{FEV}_{1}(\mathrm{R}=0.383$, 

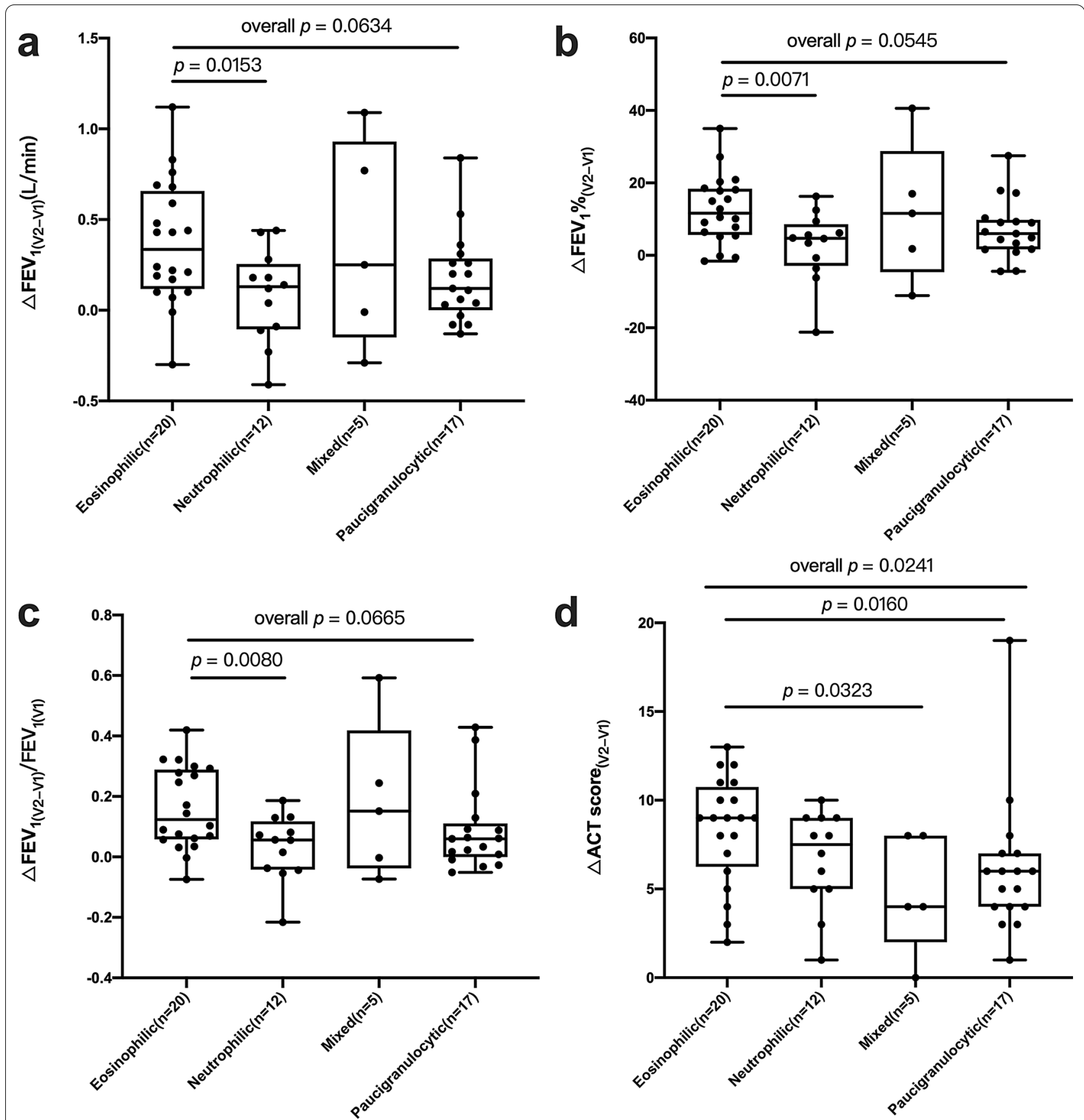

Fig. 2 The improvement of lung function $\mathbf{a}-\mathbf{c}$ and ACT scores $\mathbf{d}$ after six months standardized therapy among four subgroups of asthmatic patients. $\triangle \mathrm{FEV}_{1(\mathrm{~V} 2-\mathrm{V} 1)}$ : absolute change in $\mathrm{FEV}_{1}$, calculated by the difference between $\mathrm{FEV} 1$ after six months treatment and baseline $\mathrm{FEV}_{1}$; $\triangle \mathrm{FEV}_{1} \%_{(\mathrm{V} 2-\mathrm{V} 1)}$ : absolute change in percentage of the predicted $\mathrm{FEV}_{1}$, calculated by the difference between percentage of the predicted $\mathrm{FEV} \mathrm{V}_{1}$ after six months treatment and baseline percentage of the predicted $\mathrm{FEV}_{1} ; \Delta \mathrm{FEV}_{1\left(\mathrm{~V} 2-\mathrm{V}_{1}\right)} / \mathrm{FEV}_{1(\mathrm{~V} 1)}: \mathrm{FEV}_{1}$ change ratio, calculated by absolute change in $\mathrm{FEV}{ }_{1}$ divided by baseline $\mathrm{FEV}_{1} . \triangle \mathrm{ACT}_{(\mathrm{V} 2-\mathrm{V} 1)}$, absolute change in $\mathrm{ACT}$, calculated by the difference between $\mathrm{ACT}$ after six months treatment and baseline ACT

$p=0.004)$, absolute change in percentage of the predicted $\mathrm{FEV}_{1}(\mathrm{R}=0.382, p=0.004)$, and $\mathrm{FEV}_{1}$ change ratio $(\mathrm{R}=0.387, p=0.004)$ (Additional file 5: Table S3.1).
Subgroup analysis showed that in neutrophilic asthmatics $(n=12)$, baseline sputum cell IL-1 $\beta$ mRNA expression was negatively correlated with absolute change in $\mathrm{FEV}_{1}(\mathrm{R}=-0.624, p=0.034)$ and absolute 

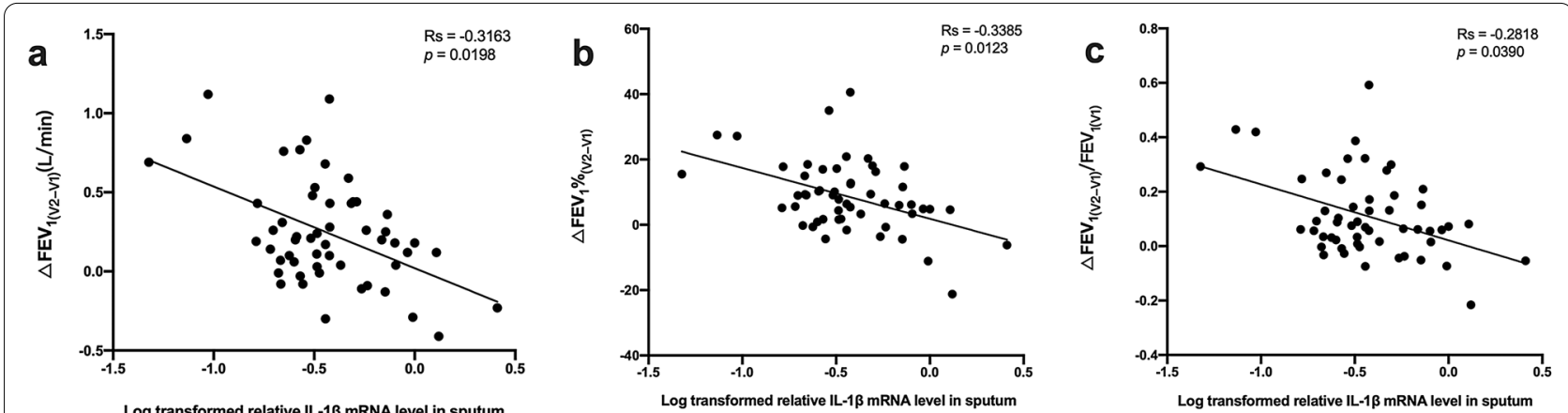

Log transformed relative IL-1 $\beta$ mRNA level in sputum

Log transformed relative IL-1 $\beta$ mRNA level in sputum
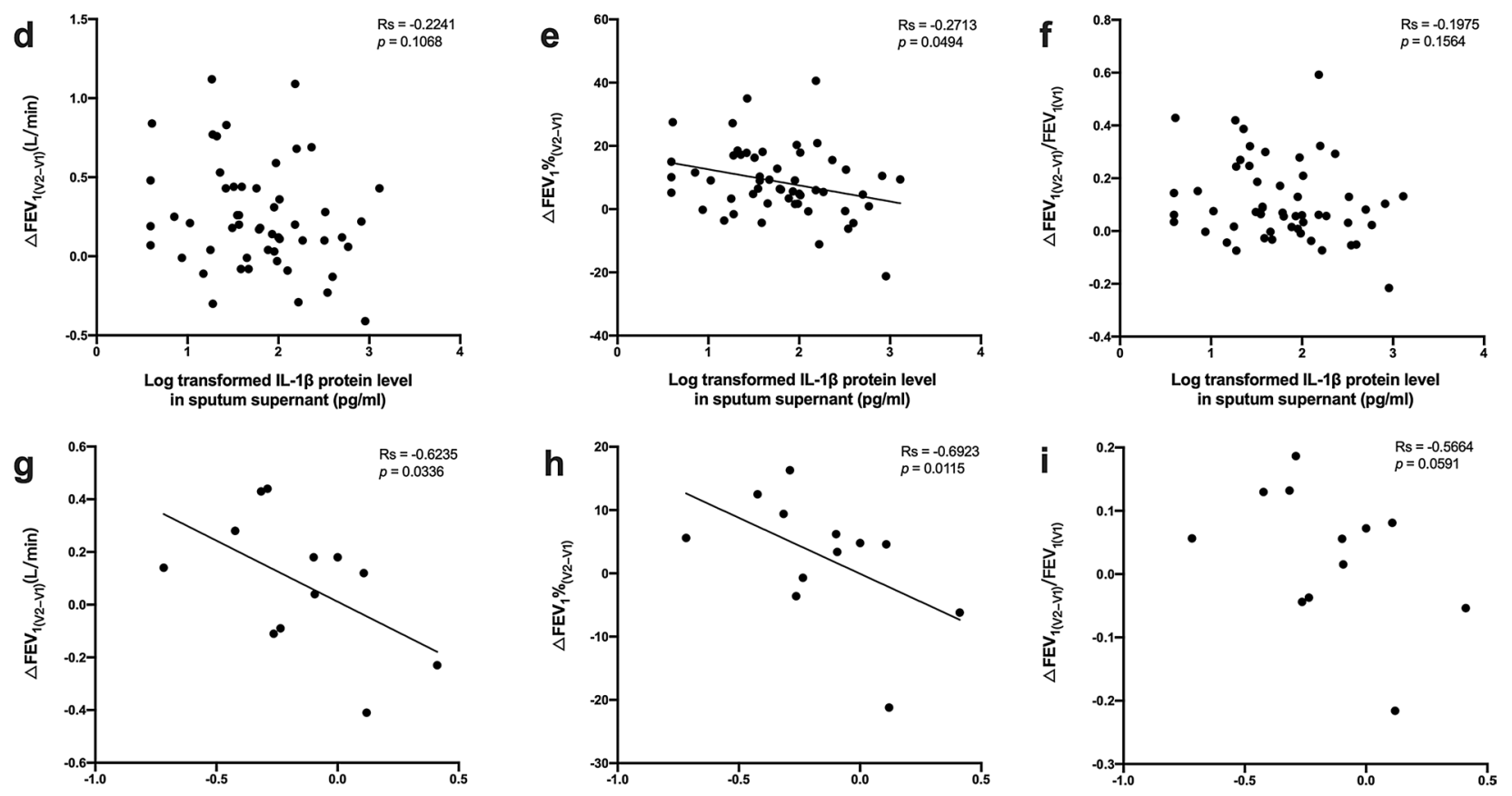

Log transformed relative IL-1 $\beta$ mRNA level in sputum
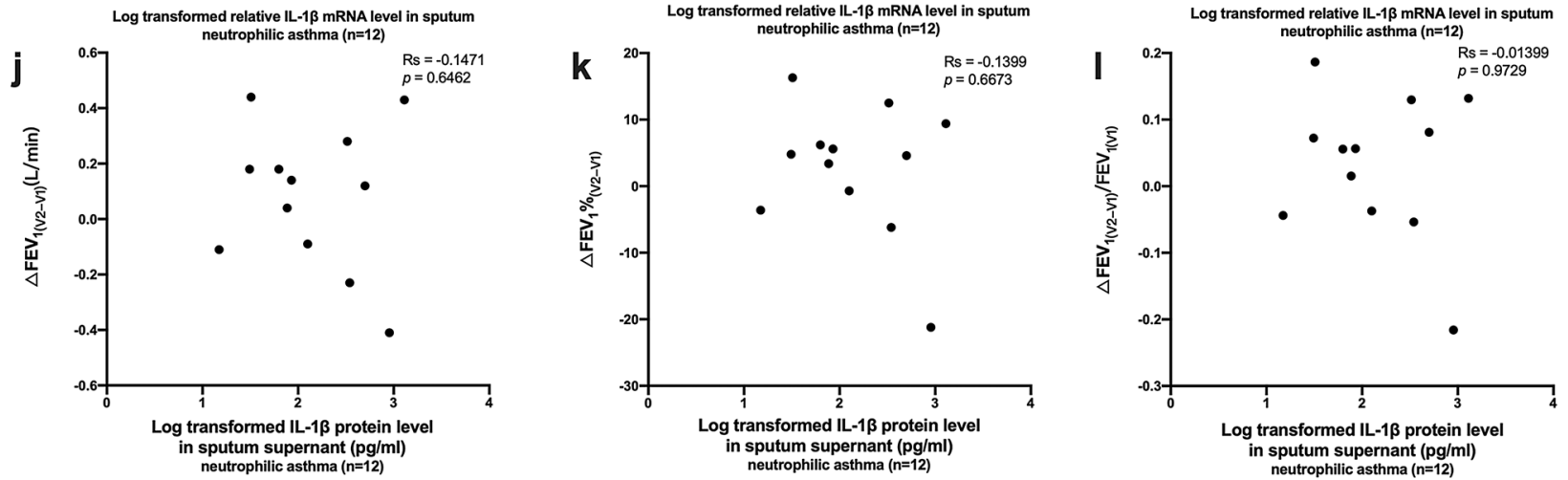

Fig. 3 a-c The correlations of baseline IL-1 $\beta$ mRNA expression with spirometry change in all asthmatic patients. $\mathbf{d}-\mathbf{f}$ The correlations of baseline IL-1 $\beta$ protein level in sputum supernatant with spirometry change in all asthmatic patients. $\mathbf{g}-\mathbf{i}$ The correlations of baseline IL-1 $\beta$ mRNA expression with spirometry change in neutrophilic asthmatic patients. $\mathbf{j}-\mathbf{I}$ The correlations of baseline IL-1 $\beta$ protein level in sputum supernatant with spirometry change in neutrophilic asthmatic patients. The data are presented as dot plots, with fitted regression lines. mRNA and protein expression were log transformed, Spearman R-values and p-values are indicated

change in percentage of the predicted $\mathrm{FEV}_{1}(\mathrm{R}=-0.692$, $p=0.012$ ), but had no significant correlation with $\mathrm{FEV}_{1}$ change ratio (Fig. 3g-i). IL-1 $\beta$ protein expression had no significant correlation with change in $\mathrm{FEV}_{1}$ (Fig. 3j-l). For the eosinophilic asthmatics $(n=20)$, neither IL-1 $\beta$ 
(See figure on next page.)

Fig. 4 The effect of IL-1 $\beta$ on TGF- $\beta 1$-induced EMT in asthmatic A549 cells. a Morphological change of A549 cells (magnification $\times 100$ ). The relative b E-cadherin and $\mathbf{c}$ Fibronectin mRNA expression were assessed by means of quantitative real-time PCR. Expression levels were normalized to the housekeeping gene $\beta$-actin and calculated over untreated control cells. $\mathbf{d}$ Western blot analyses of E-cadherin and Fibronectin in A549 cells. The relative $\mathbf{e}$ E-cadherin and $\mathbf{f}$ Fibronectin protein expression were assessed by means of western blot. Expression levels were normalized to the housekeeping gene GAPDH and calculated over untreated control cells. The figures $\mathbf{b}, \mathbf{c}$ illustrate cumulative data from 3 independent experiments. The figures $\mathbf{e}, \mathbf{f}$ illustrate cumulative data from 5 independent experiments. A549 cells were cultured in the absence ( - ) or presence (+) of IL-4, TGF- $\beta 1$, and IL-1 $\beta$. Error bars represent standard deviation. ${ }^{*} p<0.05,{ }^{* *} p<0.01,{ }^{* * *} p<0.001$ compared with control group. \#p $<0.05$ compared with TGF- $\beta 1$ treated group. $\wedge p<0.05$ compared with TGF- $\beta 1$ combined with IL-1 $\beta$ treated group

mRNA expression nor IL-1 $\beta$ protein expression had significant correlation with change in $\mathrm{FEV}_{1}$ (Additional file 5: Table S3.2). For pauci-granulocytic asthmatics $(n=17)$, IL-1 $\beta$ protein expression was negatively correlated with absolute change in percentage of the predicted $\mathrm{FEV}_{1}(\mathrm{R}=-0.495, p=0.045)$, but had no significant correlation with absolute change in $\mathrm{FEV}_{1}$ and $\mathrm{FEV}_{1}$ change ratio (Additional file 5: Table S3.4). More details were also summarized in Additional file 5: Table S3.

\section{The thickness of reticular basement membrane in asthma correlated with neutrophil percentage in BALF}

29 asthmatic patients and four healthy controls underwent bronchoscopy and yield sufficient tissue to evaluate the RBM thickness. The thickness of RBM in asthma patients was significantly greater than that of healthy controls $(9.6 \pm 3.9 \mu \mathrm{m}$ vs $4.4 \pm 1.1 \mu \mathrm{m}, \quad p=0.003)$ (Additional file 6: Figure S3a). The thickness of RBM in asthmatics was positively correlated with neutrophil percentage in bronchoalveolar lavage fluid (BALF) ( $\mathrm{R}=0.414, p=0.032)$, but had no significant correlation with eosinophil percentage in blood and eosinophil percentage in BALF (Additional file 6: Figure S3b-d).

\section{IL-1 $\beta$ augmented TGF- $\beta 1$ inducing epithelial-mesenchymal transition of epithelial cells}

Under microscopy observation, a part of A549 cells developed a spindle fibroblast-like morphology after treatment with TGF- $\beta 1$. While, treatment with IL- $1 \beta$ alone could not induce the morphological change, TGF- $\beta 1$ in combination with IL-1 $\beta$ would induce a majority of A549 cells transforming into a spindle fibroblast-like morphology (Fig. 4a). The expression of an epithelial marker, E-cadherin significantly decreased by TGF- $\beta 1$ treatment both in mRNA (Fig. 4b) and protein level (Fig. 4d and e) in A549 cells. The expression of E-cadherin mRNA was significantly lower after stimulated by TGF- $\beta 1$ in combination with IL- $1 \beta$ compared with treatment with TGF- $\beta 1$ alone. The decrease of E-cadherin mRNA in A549 cells after stimulation by TGF- $\beta 1$ in combination with IL- $1 \beta$ could be partially reversed by additional IL-4 (Fig. 4b).
The TGF- $\beta 1$ stimulation induced an increase in Fibronectin mRNA in A549 cells as well as the corresponding changes in the protein levels (Fig. 4). The expression of Fibronectin mRNA was significantly higher after stimulation by TGF- $\beta 1$ with IL- $1 \beta$ compared with that with TGF- $\beta 1$ alone. While the expression of Fibronectin was lower after stimulation by IL- 4 , TGF- $\beta 1$, and IL- $1 \beta$ compared with that with TGF- $\beta 1$ and IL-1 $\beta$ (Fig. 4c) as well as the corresponding trends in the protein levels (Fig. 4d and $\mathrm{f}$ ).

\section{Neither glucocorticoid or montelukast inhibited EMT induced by IL- $1 \beta$ and TGF- $\beta 1$ in A549 cells}

A549 cells were pretreated with glucocorticoid or montelukast sodium for $24 \mathrm{~h}$ and subsequently stimulated with TGF- $\beta 1$ in combination with IL-1 $\beta$ for two days. While TGF- $\beta 1$ in combination with IL- $1 \beta$ significantly decreased E-cadherin and increased Fibronectin in A549 cells, neither glucocorticoid or montelukast sodium of pretreatment could inhibit the change of EMT protein expression (Additional file 7: Figure S4).

\section{MAPK signaling pathways mediated IL-1 $\beta$ augmenting epithelial-mesenchymal transition of epithelial cells}

To further investigate the mechanism of IL-1 $\beta$ augmenting TGF- $\beta 1$ inducing EMT, Western Blot was used to detect the expression of candidate signaling pathways related proteins. The results showed that after the stimulation by TGF- $\beta 1$ with IL- $1 \beta$, the expression of $\mathrm{p}-\mathrm{ERK} 1 / 2$, p-JNK1/2, and p-p38 increased significantly in A549 cells compared with control group and the group stimulated with TGF- $\beta 1$ alone (Fig. $5 \mathrm{a}-\mathrm{d}$ ). Both MEK inhibitor U0126, p-JNK1/2 inhibitor SP600125, and p38 inhibitor SB203580 significantly inhibited the expression of Fibronectin induced by TGF- $\beta 1$ in combination with IL-1 $\beta$ (Fig. 5e-g). P38 inhibitor SB203580 could partially reverse the inhibitory effect of TGF- $\beta 1$ with and without IL-1 $\beta$ on E-cadherin expression in A549 cells (Fig. 5g).

\section{Discussion}

There is increasing evidence that asthma is a heterogeneous inflammatory airway disorder involving Th2-driven and non-Th2-driven mechanisms approximately half by 

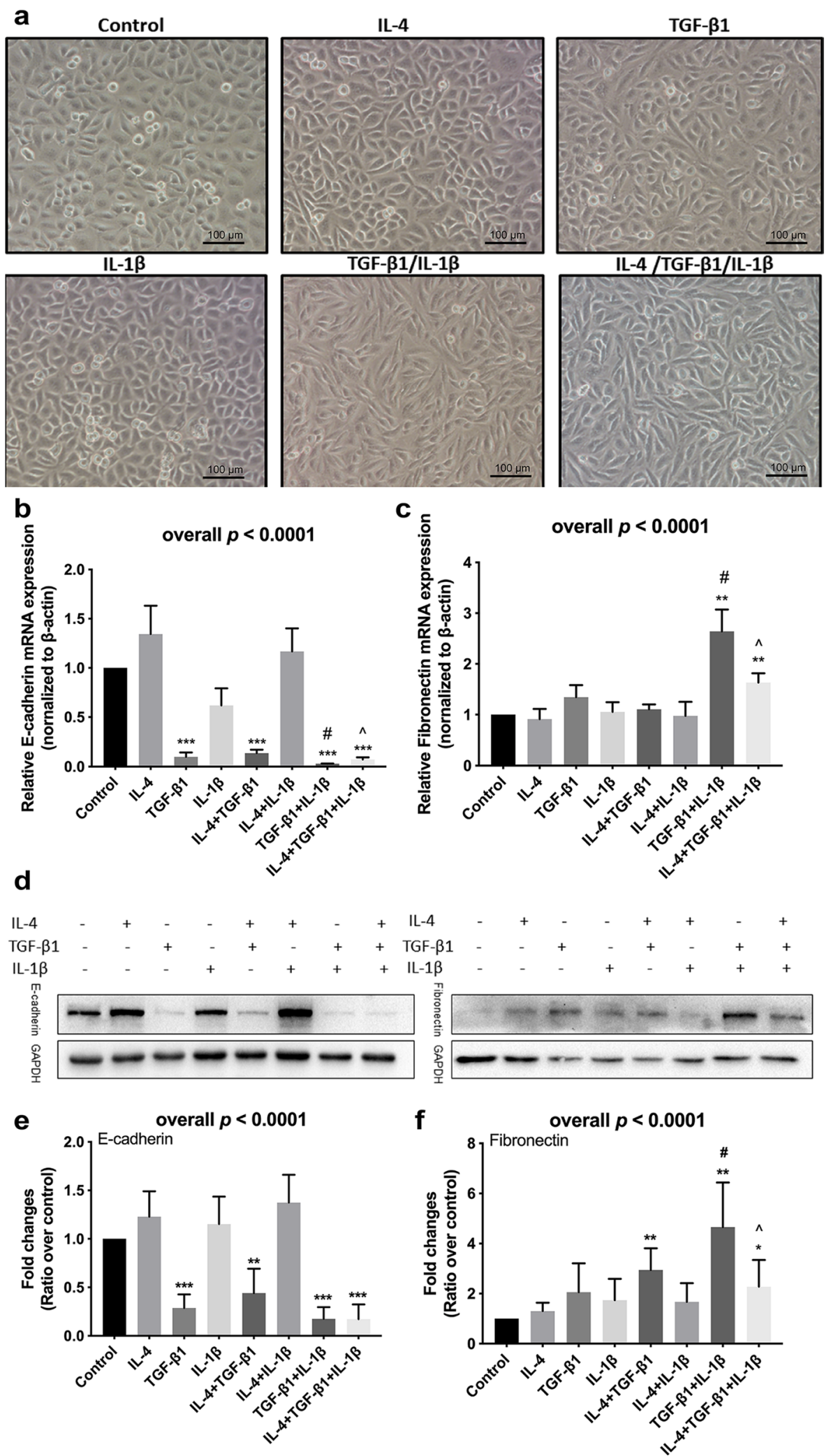

Fig. 4 (See legend on previous page.) 


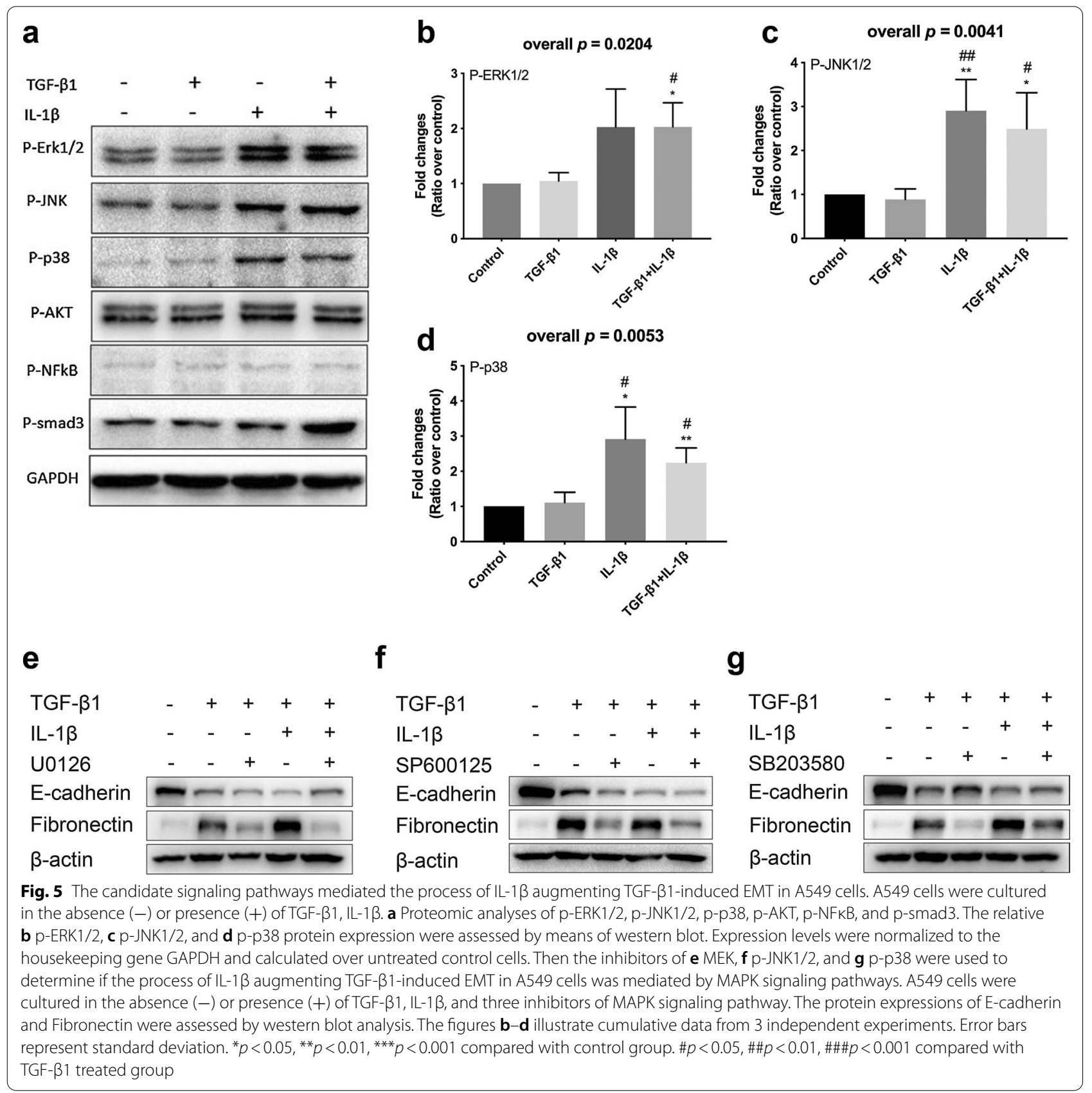

half [14]. Recent studies demonstrate non-Th2 inflammation in asthma may lead to poor control of asthma. Especially, the asthmatic patients who have neutrophilpredominant airway inflammation defined by induced sputum cell counts, had less improvement in lung function and symptoms control after treatment with inhaled corticosteroids [15]. To our best knowledge, this is the first study that revealed higher IL-1 $\beta$ expression in sputum may predict less improvement of lung function in neutrophilic asthma patients.
In this study, we picked cytokines in sputum which represent innate immune response or Th2 immune response. Our findings are consistent with recent studies that the sputum mRNA and protein expression levels of IL-1 $\beta$ were significantly elevated in neutrophilic asthmatics [2] and the sputum mRNA expression levels of IL-5 mRNA were significantly elevated in eosinophilic asthmatic patients which confirmed the effect of IL-5 on eosinophilic inflammation [16]. This consistency shows that our results are reliable. Neutrophilic asthmatics had 
less improvement in $\mathrm{FEV}_{1}$ (calculated in three ways) as compared with eosinophilic asthmatics. The results have shown that baseline sputum IL- $1 \beta$ mRNA and protein expression were negatively correlated with the improvement of lung function, eosinophil percentage was positively correlated with the improvement of lung function for all asthmatics. However, for neutrophilic asthmatics, categorized by sputum eosinophils and neutrophils count, only IL-1 $\beta$ mRNA expression correlated with the less improvement of lung function, indicating that IL-1 $\beta$ may be an important biomarker for poor lung function improvement in neutrophilic asthmatics.

Patients with impaired lung function are inclined to have acute exacerbation, poor quality of life and uncontrolled asthma [17]. However, those neutrophilic asthmatics, which had poor lung function improvement after standardized therapy, had no statistical difference in baseline lung function and symptoms scores compared with asthmatics with other phenotypes, and there is no significant correlation between neutrophil percentage and lung function improvement, means that it is difficult to distinguish asthmatics who may have worse lung function from all patients in the early stage. The results of this study show a possibility that baseline sputum cell IL- $1 \beta$ mRNA expression may be used as a predictive factor for less lung function improvement in neutrophilic asthmatics.

IL-1 $\beta$ elevation has been reported in asthmatics with sputum neutrophilia in several recent studies $[2,18,19]$. Evans et al. have reported that IL-1 receptor as an important predictor of both neutrophilic asthma and worse lung functions, however, IL-1 $\beta$ was not measured in their study [20]. Juan-juan et al. observed a trend of increased IL-1 $\beta$ gene and protein expression in asthmatics with frequent exacerbations [12]. IL-1 $\beta$ was also confirmed to be involved in the viral stimulus-induced asthma exacerbation [21, 22]. Due to the small sample size of asthmatics with at least one exacerbation during six months of follow-up period (only three patients), we could not analyze the relationship between IL-1 $\beta$ mRNA expression and asthma exacerbation in our study. IL-1 $\beta$ and IL-1 signaling were also found to contribute to lung neutrophilic inflammation, which negatively impacts lung function in experimental fungal-associated asthma mice model [23]. These studies have shown that IL- $1 \beta$ plays an important role in airway inflammation, especially neutrophil inflammation, in bronchial asthma.

However, it is not clear how IL- $1 \beta$ affects lung function in asthmatic patients. Mehta et al. have found that IL-1 $\beta$ is essential in recurrent rhinovirus infection induced airway remodeling in the absence of allergen [24].This finding suggests that IL-1 $\beta$ may contribute to the decline of lung function by promoting airway remodeling. In our study, we found that mean thickness of RBM in asthma was significantly greater than that of healthy controls. For asthmatic patients, the thickness of RBM was positively correlated with neutrophil percentage in BALF, indicating that airway neutrophilic inflammation may play an important role in airway remodeling. EMT is regarded as an important pathophysiological process in airway remodeling in asthmatic patients [9]. Previous studies have demonstrated that IL-1 $\beta$ can induce EMT or endothelial-to-mesenchymal in a variety of epithelial or endothelial cells, such as hepatocellular carcinoma cells, esophageal squamous cell carcinoma cells, aortic endothelial cells, and so on [25-27]. However, in human bronchial epithelial cell lines the results are inconsistent, a previous study found that stimulation with IL-1 $\beta$ alone cannot induce EMT [28]. Other studies found that IL-1 $\beta$ alone can induce a significant reduction in E-cadherin protein expression [29, 30]. E-cadherin is usually expressed in the cell membrane adhering junctions of epithelial cells, which connects epithelial cells together, the decrease of E-cadherin can be a marker of EMT [31]. In our study, treatment with IL- $1 \beta$ individually could not induce changes in morphological or EMT markers expression in A549 cells. Transforming growth factor- $\beta$ $($ TGF- $\beta$ ), a multifunctional cytokine that induces tissue fibrosis, is the main factor responsible for driving EMT [32]. As IL-1 $\beta$ was negatively correlated with the improvement of lung function, we hypothesized that IL-1 $\beta$ augmented TGF- $\beta 1$ induced EMT of human lung epithelial cells. Our results showed that TGF- $\beta 1$ induced part of A549 cells developed a spindle fibroblast-like morphology, and IL-1 $\beta$ could significantly enhance this effect. Interestingly, when add together with IL-4, after treatment with IL-4/TGF- $\beta 1 / \mathrm{IL}-1 \beta$, the proportion of cell morphological changes seems to have decreased compared with treatment with TGF- $\beta 1 /$ IL-1 $\beta$. At the mRNA and protein level, this effect has been confirmed. These results indicate that IL-4 can partly reverse EMT induced by TGF- $\beta 1 / \mathrm{IL}-1 \beta$. This may be one of the reasons why eosinophilic asthmatics had more improvement of lung function after therapy as compared with neutrophilic asthmatics.

Glucocorticoid and leukotriene receptor antagonists (LTRA) are the most commonly used drugs in the therapy of asthma [33].The abilities of dexamethasone and fluticasone propionate to inhibit MMP-2 expression, which has been associated with airway remodeling, induced by cigarette smoke extract have been demonstrated [34]. Budesonide can inhibit chlorine-induced airway fibrosis [35]. And the effect of LTRA on attenuate airway remodeling by inhibiting TGF- $\beta /$ Smad signaling has been also demonstrated [36]. However, recent studies 
have also focused on the ineffective of glucocorticoid in treating airway remodeling $[37,38]$. Our results showed that neither glucocorticoid or montelukast sodium can reverse the changes of EMT markers induced by TGF$\beta 1 / \mathrm{IL}-1 \beta$. This may explain why neutrophilic asthmatics with higher airway IL-1 $\beta$ expression had poor lung function improvement although they also received sufficient standardized therapy.

Previous studies have demonstrated the critical role of MAPK signaling pathways (such as ERK1/2, JNK, and p38 signaling pathways) and other signaling pathways (such as PI3K/AKT, NF-kb, and Smads signaling pathways) in EMT induced by TGF- $\beta 1$ or other cytokines and airway remodeling [39-46].Some of drugs, chemicals, and probiotics can alleviate airway remodeling through attenuation these signaling pathways [38, 47-50]. To further investigate the mechanism of IL- $1 \beta$ augmenting TGF- $\beta 1$ induced EMT, candidate signaling pathways related proteins were detected. In our cellular model, we find that TGF- $\beta 1$ combine with IL- $1 \beta$, but not TGF$\beta 1$ alone, induces ERK1/2, JNK1/2, and p38 activation. Inhibitors of MEK, p-JNK1/2, and p-p38 can reverse the changes of EMT markers induced by TGF- $\beta 1 /$ IL- $1 \beta$. These results indicate that IL- $1 \beta$ may act through MAPK signaling pathways to augment TGF- $\beta 1$ induced EMT.

Evidences show that IL-17A is associated with airway neutrophilic inflammation in asthmatic patients through promoting neutrophils recruitment and accumulation by inducing cytokines released from structural cells, such as bronchial epithelial and venous endothelial cells [51]. In this study, the expression of IL-17A mRNA was not increased in sputum of neutrophilic asthma in this study. The reasons may be due to several issues. Firstly, the sputum may differ from the epithelial cells or bronchial biopsy in IL-17 expression. Previous literatures reported gene expressions of IL-17 response signatures in epithelial brushing or bronchial biopsy can be used to identify an IL-17-high asthma phenotype [52]. However, Manise et al. [53] have reported that IL-17 levels in sputum supernatant of neutrophilic asthmatics were similar to those of eosinophilic or pauci-granulocytic asthmatics. Another study showed that, in steroid-naïve asthmatic patients, IL-17A mRNA levels in sputum did not significantly correlate with the percentage of neutrophil in sputum [54]. In our study, all patients were steroid-naïve at the time of enrollment. Secondly, in this study, the IL-17A mRNA significantly increased in the mixed phenotype of asthma patients compared with pauci-granulocytic phenotype. Molet et al. [55] have demonstrated that eosinophils in asthmatic airway expressed IL-17. Wakashin et al. [56] showed that IL-23/IL-17A axis enhances Th2 cytokine mediated eosinophil recruitment into the airways. A novel subset of dual-positive Th2/ Th17 cells co-expressing IL-4 and IL-17 was identified and the number of this subset cells was positively correlated with eosinophil count in BALF [56]. In addition, the frequency of circulation Th2 cells that produce both IL-17A and classical Th2 cytokines (IL-4, IL-5, and IL-13) is higher in patients with atopic asthma than healthy controls [57]. These studies showed a significant crosstalk exists between IL-17 and eosinophilic inflammation which may explain why IL-17A mRNA significantly increased in asthmatics with mixed-granulocytic phenotype, a special phenotype with both neutrophilic and eosinophilic inflammation. Finally, the mRNA expression of IL-17A may not be consistent with its protein expression. We have tried to measure IL-17 protein in sputum supernatant by ELISA. However, sputum IL-17 was below the limit of detection in all samples. This may be caused by DTT $(0.1 \%$ concentration) used in our study decreased the level of IL-17 in sputum supernatant [58] and made it below the limit of detection [59].

Of note, in our study, healthy controls were younger than asthmatic patients, although the difference of age among the four asthmatic subgroups were not significant. While the six genes included in this study were carefully chosen to characterize the innate and type-2 adaptive immunity, testing a larger number of cytokines using high-throughput approaches will provide a full understanding of the immune network in neutrophilic asthmatics. We also note, previous study defined persistent inflammation as stability of elevated inflammatory markers over one year [60], thus sampling only once may not represent persistent inflammation levels. Finally, the subjects in this study are relatively mild asthma patients which may differ with the severe asthma patients in the mechanism of airway remodeling.

\section{Conclusions}

In conclusion, we have identified IL- $1 \beta$ mRNA in induced sputum of untreated asthmatics as an important predictor for poor lung function improvement at response of 6-month standardized therapy in neutrophilic asthmatics. The underlying mechanism is related to IL- $1 \beta$ augmenting TGF- $\beta 1$ induced EMT through MAPK signaling pathways, and this process cannot be abrogated by glucocorticoid or LTRA. 


\section{Abbreviations}

ACT: Asthma Control Test; BALF: Bronchoalveolar lavage fluid; BMI: Body mass index; ELISA: Enzyme-linked immunosorbent assay; EMT: Epithelial-mesen-

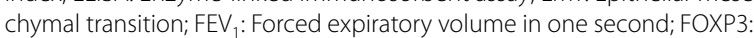
Forkhead box protein 3; IFN: Interferon; IL: Interleukin; LTRA: Leukotriene receptor antagonists; RBM: Reticular basement membrane; RT-qPCR: Quantitative reverse transcription; TGF: Transforming growth factor.

\section{Supplementary Information}

The online version contains supplementary material available at https://doi. org/10.1186/s12931-021-01808-7.

Additional file 1: Figure S1. The baseline sputum cell mRNA levels among four subgroups of asthmatic patients.

Additional file 2: Table S1. The correlations among baseline sputum cell mRNA expression and induced sputum cell counts of asthmatic patients $(n=115)$.

Additional file 3: Table S2. Baseline demographic characteristics of asthmatic patients with spirometry follow up $(n=54)$.

Additional file 4: Figure S2. Lung function and ACT scores after 6 months standardized therapy among four subgroups of asthmatic patients.

Additional file 5: Table S3. The correlations among baseline sputum inflammatory factors and spirometry change in asthmatic patients.

Additional file 6: Figure S3. The thickness of RBM was increased in asthmatics and positively correlated with neutrophil percentage in BALF.

Additional file 7: Figure S4. The effect of glucocorticoid and montelukast sodium on TGF- $\beta 1$ combined with IL-1 $\beta$-induced EMT in A549 cells.

\section{Acknowledgements}

Not applicable.

\section{Authors' contributions}

$M X$ and $X L$ had full access to all the data in the study and take responsibility for the integrity of the data and the accuracy of the data analysis. $S Z, Y F, X L$, and $M X$ participated in study conception; SZ, YF, LQ, XF, CZ, JY, WB, XL, and $M X$ acquired the data; $S Z, Y F, L Q$, and $M X$ participated in experiment; $S Z, Y F$, GW, ZC, HR, CS, and MX contributed substantially to the data analysis and interpretation; SZ, YF, and MX drafted and revised the paper. All authors read and approved the final manuscript.

\section{Funding}

This project was supported by grants from the National Natural Science Foundation of China (81670020). Chrysanthi Skevaki is supported by the Universities Giessen and Marburg Lung Center (UGMLC), the German Center for Lung Research (DZL), University Hospital Giessen and Marburg (UKGM) research funding according to article 2, Section 3 cooperation agreement, and the Deutsche Forschungsgemeinschaft (DFG)-funded SFB 1021 (C04), KFO 309 (P10), and SK 317/1-1 (Project number 428518790) as well as by the Foundation for Pathobiochemistry and Molecular Diagnostics.

\section{Availability of data and materials}

The datasets generated during and/or analyzed during the current study are available from the corresponding author on reasonable request.

\section{Declarations}

Ethics approval and consent to participate

This study was approved by the Ethics Committee of Tongji Hospital, Tongji Medical College, Huazhong University of Science and Technology (IRB ID: 20150406).

\section{Consent for publication}

Not applicable.

\section{Competing interests}

Shengding Zhang: No conflicts to declare. Yu Fan: No conflicts to declare. Lu Qin: No conflicts to declare. Xiaoyu Fang: No conflicts to declare. Cong Zhang: No conflicts to declare. Junqin Yue: No conflicts to declare. Wenxue Bai: No conflicts to declare. Gang Wang: No conflicts to declare. Zhihong Chen: No conflicts to declare. Harld Renz: No conflicts to declare. Chrysanthi Skevaki: Consultancy and research funding, Hycor Biomedical, Bencard Allergie and Thermo Fisher Scientific; Research Funding, Mead Johnson Nutrition (MJN). Xiansheng Liu: No conflicts to declare. Min Xie: No conflicts to declare.

\section{Author details}

${ }^{1}$ Department of Respiratory and Critical Care Medicine, Shanxi Bethune Hospital, Shanxi Academy of Medical Sciences, Tongji Shanxi Hospital, Third Hospital of Shanxi Medical University, Taiyuan 030032, China. ${ }^{2}$ Department of Respiratory and Critical Care Medicine, Tongji Hospital, Tongji Medical College, Huazhong University of Science and Technology, Wuhan, China. ${ }^{3}$ Key Laboratory of Respiratory Diseases, National Ministry of Health of the People's Republic of China and National Clinical Research Center for Respiratory Disease, Wuhan, China. ${ }^{4}$ Department of Respiratory and Critical Care Medicine, Qiandongnanzhou People's Hospital, Kaili, China. ${ }^{5}$ Department of Respiratory and Critical Care Medicine, Clinical Research Center for Respiratory Disease, West China Hospital, Sichuan University, Chengdu, China. ${ }^{6}$ Department of Respiratory and Critical Care Medicine, Zhongshan Hospital, Fudan University, Shanghai, China. ${ }^{7}$ Institute of Laboratory Medicine, Philipps Universität Marburg, Marburg, Germany. ${ }^{8}$ Universities of Giessen and Marburg Lung Center (UGMLC), and the German Center for Lung Research (DZL), Marburg, Germany.

Received: 30 March 2021 Accepted: 23 July 2021

Published online: 03 August 2021

\section{References}

1. Kim RY, Pinkerton JW, Gibson PG, Cooper MA, Horvat JC, Hansbro PM. Inflammasomes in COPD and neutrophilic asthma. Thorax. 2015;70:1199-201.

2. Simpson JL, Phipps S, Baines KJ, Oreo KM, Gunawardhana L, Gibson PG. Elevated expression of the NLRP3 inflammasome in neutrophilic asthma. Eur Respir J. 2014;43:1067-76.

3. Global Strategy for Asthma Management and Prevention. Global initiative for asthma. 2020 https://ginasthma.org/gina-reports/. Accessed 18 Jun 2020.

4. Osborne ML, Pedula KL, O'Hollaren M, Ettinger KM, Stibolt T, Buist AS, Vollmer WM. Assessing future need for acute care in adult asthmatics: the Profile of Asthma Risk Study: a prospective health maintenance organization-based study. Chest. 2007:132:1151-61.

5. Kitch BT, Paltiel AD, Kuntz KM, Dockery DW, Schouten JP, Weiss ST, Fuhlbrigge AL. A single measure of FEV1 is associated with risk of asthma attacks in long-term follow-up. Chest. 2004;126:1875-82.

6. Ulrik CS. Outcome of asthma: longitudinal changes in lung function. Eur Respir J. 1999;13:904-18.

7. Kerstjens HA, Brand PL, de Jong PM, Koeter GH, Postma DS. Influence of treatment on peak expiratory flow and its relation to airway hyperresponsiveness and symptoms. The Dutch CNSLD Study Group. Thorax. 1994:49:1109-15

8. Boonpiyathad T, Sozener ZC, Satitsuksanoa P, Akdis CA. Immunologic mechanisms in asthma. Semin Immunol. 2019:46:101333.

9. Knight DA, Grainge CL, Stick SM, Kicic A, Schuliga M. Epithelial mesenchymal transition in respiratory disease: fact or fiction. Chest. 2020;157:1591-6.

10. Ward H, Cooper BG, Miller MR. Improved criterion for assessing lung function reversibility. Chest. 2015;148:877-86.

11. Simpson JL, Carroll M, Yang IA, Reynolds PN, Hodge S, James AL, Gibson PG, Upham JW. Reduced antiviral interferon production in poorly controlled asthma is associated with neutrophilic inflammation and highdose inhaled corticosteroids. Chest. 2016;149:704-13.

12. Fu JJ, McDonald VM, Baines KJ, Gibson PG. Airway IL-1 beta and systemic inflammation as predictors of future exacerbation risk in asthma and COPD. Chest. 2015;148:618-29.

13. Sont JK, Willems LN, Bel EH, van Krieken JH, Vandenbroucke JP, Sterk PJ. Clinical control and histopathologic outcome of asthma when 
using airway hyperresponsiveness as an additional guide to longterm treatment. The AMPUL Study Group. Am J Respir Crit Care Med. 1999;159:1043-51.

14. Woodruff PG, Modrek B, Choy DF, Jia G, Abbas AR, Ellwanger A, Koth LL, Arron JR, Fahy JV. T-helper type 2-driven inflammation defines major subphenotypes of asthma. Am J Respir Crit Care Med. 2009;180:388-95.

15. Green RH, Brightling CE, Woltmann G, Parker D, Wardlaw AJ, Pavord ID. Analysis of induced sputum in adults with asthma: identification of subgroup with isolated sputum neutrophilia and poor response to inhaled corticosteroids. Thorax. 2002;57:875-9.

16. Shrimanker R, Pavord ID. Interleukin-5 Inhibitors for Severe Asthma: Rationale and Future Outlook. BioDrugs. 2017;31:93-103.

17. Chung KF, Wenzel SE, Brozek JL, Bush A, Castro M, Sterk PJ, Adcock IM, Bateman ED, Bel EH, Bleecker ER, et al. International ERS/ATS guidelines on definition, evaluation and treatment of severe asthma. Eur Respir J. 2014;43:343-73.

18. Hastie AT, Moore WC, Meyers DA, Vestal PL, Li H, Peters SP, Bleecker ER, National Heart L. Blood institute severe asthma research P: Analyses of asthma severity phenotypes and inflammatory proteins in subjects stratified by sputum granulocytes. J Allergy Clin Immunol. 2010;125:10281036.e1013.

19. Son JH, Kim JH, Chang HS, Park JS, Park CS. Relationship of Microbial Profile With Airway Immune Response in Eosinophilic or Neutrophilic Inflammation of Asthmatics. Allergy Asthma Immunol Res. 2020;12:412-29.

20. Evans MD, Esnault S, Denlinger LC, Jarjour NN. Sputum cell IL-1 receptor expression level is a marker of airway neutrophilia and airflow obstruction in asthmatic patients. J Allergy Clin Immunol. 2018;142:415-23.

21. Mahmutovic Persson I, Menzel M, Ramu S, Cerps S, Akbarshahi H, Uller L. IL-1 beta mediates lung neutrophilia and IL-33 expression in a mouse model of viral-induced asthma exacerbation. Respir Res. 2018;19:16.

22. Hossain FMA, Park SO, Kim HJ, Eo JC, Choi JY, Uyangaa E, Kim B, Kim K, Eo SK. CCR5 attenuates neutrophilic airway inflammation exacerbated by infection with rhinovirus. Cell Immunol. 2020;351:104066.

23. Godwin MS, Reeder KM, Garth JM, Blackburn JP, Jones M, Yu Z, Matalon S, Hastie AT, Meyers DA, Steele C. IL-1RA regulates immunopathogenesis during fungal-associated allergic airway inflammation. JCI Insight. 2019. https://doi.org/10.1172/jci.insight.129055.

24. Mehta AK, Doherty T, Broide D, Croft M. Tumor necrosis factor family member LIGHT acts with IL-1 beta and TGF-beta to promote airway remodeling during rhinovirus infection. Allergy. 2018;73:1415-24.

25. Zhang J, Zhang Q, Lou Y, Fu Q, Chen Q, Wei T, Yang J, Tang J, Wang J, Chen Y, et al. Hypoxia-inducible factor-1alpha/interleukin-1 beta signaling enhances hepatoma epithelial-mesenchymal transition through macrophages in a hypoxic-inflammatory microenvironment. Hepatology. 2018;67:1872-89.

26. Zhou J, Zheng S, Liu T, Liu Q, Chen Y, Tan D, Ma R, Lu X. IL-1 beta from M2 macrophages promotes migration and invasion of ESCC cells enhancing epithelial-mesenchymal transition and activating NF-kappaB signaling pathway. J Cell Biochem. 2018;119:7040-52.

27. Sanchez-Duffhues G, de Garcia Vinuesa A, van de Pol V, Geerts ME, de Vries MR, Janson SG, van Dam H, Lindeman JH, Goumans MJ, Ten Dijke P. Inflammation induces endothelial-to-mesenchymal transition and promotes vascular calcification through downregulation of BMPR2. J Pathol. 2019;247:333-46.

28. Borthwick LA, Mcllroy El, Gorowiec MR, Brodlie M, Johnson GE, Ward C, Lordan JL, Corris PA, Kirby JA, Fisher AJ. Inflammation and epithelial to mesenchymal transition in lung transplant recipients: role in dysregulated epithelial wound repair. Am J Transplant. 2010;10:498-509.

29. Corvol H, Rousselet N, Thompson KE, Berdah L, Cottin G, Foussigniere T, Longchampt E, Fiette L, Sage E, Prunier C, et al. FAM13A is a modifier gene of cystic fibrosis lung phenotype regulating rhoa activity, actin cytoskeleton dynamics and epithelial-mesenchymal transition. J Cyst Fibros. 2018;17:190-203.

30. Doerner AM, Zuraw BL. TGF-beta1 induced epithelial to mesenchymal transition (EMT) in human bronchial epithelial cells is enhanced by IL1 beta but not abrogated by corticosteroids. Respir Res. 2009;10:100

31. Wong SHM, Fang CM, Chuah LH, Leong CO, Ngai SC. E-cadherin: Its dysregulation in carcinogenesis and clinical implications. Crit Rev Oncol Hematol. 2018;121:11-22.

32. Xu J, Lamouille S, Derynck R. TGF-beta-induced epithelial to mesenchymal transition. Cell Res. 2009;19:156-72.
33. McCracken JL, Veeranki SP, Ameredes BT, Calhoun WJ. Diagnosis and management of asthma in adults: a review. JAMA. 2017;318:279-90.

34. Park JH, Shin JM, Yang HW, Kim TH, Lee SH, Lee HM, Cho JG, Park IH. Cigarette smoke extract stimulates MMP-2 production in nasal fibroblasts via ROS/PI3K, Akt, and NF-kappaB signaling pathways. Antioxidants (Basel). 2020. https://doi.org/10.3390/antiox9080739.

35. Musah S, Chen J, Schlueter C, Humphrey DM Jr, Stocke K, Hoyle MI, Hoyle GW. Inhibition of chlorine-induced airway fibrosis by budesonide. Toxicol Appl Pharmacol. 2019;363:11-21.

36. Hur J, Kang JY, Rhee CK, Kim YK, Lee SY. The leukotriene receptor antagonist pranlukast attenuates airway remodeling by suppressing TGF-beta signaling. Pulm Pharmacol Ther. 2018;48:5-14.

37. Royce SG, Mao W, Lim R, Kelly K, Samuel CS. iPSC- and mesenchymoangioblast-derived mesenchymal stem cells provide greater protection against experimental chronic allergic airways disease compared with a clinically used corticosteroid. FASEB J. 2019;33:6402-11.

38. Yap HM, Lee YZ, Harith HH, Tham CL, Cheema MS, Shaari K, Israf DA. The geranyl acetophenone tHGA attenuates human bronchial smooth muscle proliferation via inhibition of AKT phosphorylation. Sci Rep. 2018;8:16640

39. Xie L, Law BK, Chytil AM, Brown KA, Aakre ME, Moses HL. Activation of the Erk pathway is required for TGF-beta1-induced EMT in vitro. Neoplasia. 2004;6:603-10.

40. Yu L, Hebert MC, Zhang YE. TGF-beta receptor-activated p38 MAP kinase mediates Smad-independent TGF-beta responses. EMBO J. 2002;21:3749-59.

41. Santibanez JF. JNK mediates TGF-beta1-induced epithelial mesenchymal transdifferentiation of mouse transformed keratinocytes. FEBS Lett. 2006;580:5385-91.

42. Bakin AV, Tomlinson AK, Bhowmick NA, Moses HL, Arteaga CL. Phosphatidylinositol 3-kinase function is required for transforming growth factor beta-mediated epithelial to mesenchymal transition and cell migration. J Biol Chem. 2000;275:36803-10.

43. Wu Y, Deng J, Rychahou PG, Qiu S, Evers BM, Zhou BP. Stabilization of snail by NF-kappaB is required for inflammation-induced cell migration and invasion. Cancer Cell. 2009;15:416-28.

44. Julien S, Puig I, Caretti E, Bonaventure J, Nelles L, van Roy F, Dargemont C, de Herreros AG, Bellacosa A, Larue L. Activation of NF-kappaB by Akt upregulates Snail expression and induces epithelium mesenchyme transition. Oncogene. 2007;26:7445-56.

45. Kim HJ, Litzenburger BC, Cui X, Delgado DA, Grabiner BC, Lin X, Lewis MT, Gottardis MM, Wong TW, Attar RM, et al. Constitutively active type I insulin-like growth factor receptor causes transformation and xenograft growth of immortalized mammary epithelial cells and is accompanied by an epithelial-to-mesenchymal transition mediated by NF-kappaB and snail. Mol Cell Biol. 2007;27:3165-75.

46. Thuault S, Tan EJ, Peinado H, Cano A, Heldin CH, Moustakas A. HMGA2 and Smads co-regulate SNAIL1 expression during induction of epithelialto-mesenchymal transition. J Biol Chem. 2008;283:33437-46.

47. Pan J, Yang Q, Zhou Y, Deng H, Zhu Y, Zhao D, Liu F. MicroRNA-221 modulates airway remodeling via the PI3K/AKT pathway in OVA-Induced chronic murine asthma. Front Cell Dev Biol. 2020;8:495.

48. Lee YZ, Yap HM, Shaari K, Tham CL, Sulaiman MR, Israf DA. Blockade of eosinophil-induced bronchial epithelial-mesenchymal transition with a geranyl acetophenone in a coculture model. Front Pharmacol. 2017;8:837

49. Anatriello E, Cunha M, Nogueira J, Carvalho JL, Sa AK, Miranda M, CastroFaria-Neto H, Keller AC, Aimbire F. Oral feeding of Lactobacillus bulgaricus N45.10 inhibits the lung inflammation and airway remodeling in murine allergic asthma: Relevance to the Th1/Th2 cytokines and STAT6/T-bet. Cell Immunol. 2019;341:103928.

50. Sethi GS, Sharma S, Naura AS. PARP inhibition by olaparib alleviates chronic asthma-associated remodeling features via modulating inflammasome signaling in mice. IUBMB Life. 2019;71:1003-13.

51. Linden A, Dahlen B. Interleukin-17 cytokine signalling in patients with asthma. Eur Respir J. 2014;44:1319-31.

52. Ostling J, van Geest M, Schofield JPR, Jevnikar Z, Wilson S, Ward J, Lutter R, Shaw DE, Bakke PS, Caruso M, et al. IL-17-high asthma with features of a psoriasis immunophenotype. J Allergy Clin Immunol. 2019;144:1198-213. 
53. Manise M, Holtappels G, Van Crombruggen K, Schleich F, Bachert C, Louis R. Sputum IgE and cytokines in asthma: relationship with sputum cellular profile. PLOS ONE. 2013;8:e58388.

54. Bullens DM, Truyen E, Coteur L, Dilissen E, Hellings PW, Dupont LJ, Ceuppens JL. IL-17 mRNA in sputum of asthmatic patients: linking T cell driven inflammation and granulocytic influx? Respir Res. 2006;7:135.

55. Molet S, Hamid Q, Davoine F, Nutku E, Taha R, Page N, Olivenstein R, Elias J, Chakir J. IL-17 is increased in asthmatic airways and induces human bronchial fibroblasts to produce cytokines. J Allergy Clin Immunol. 2001;108:430-8.

56. Wakashin H, Hirose K, Maezawa Y, Kagami S, Suto A, Watanabe N, Saito Y, Hatano M, Tokuhisa T, Iwakura Y, et al. IL-23 and Th17 cells enhance Th2cell-mediated eosinophilic airway inflammation in mice. Am J Respir Crit Care Med. 2008;178:1023-32.

57. Wang YH, Voo KS, Liu B, Chen CY, Uygungil B, Spoede W, Bernstein JA, Huston DP, Liu YJ. A novel subset of CD4(+)T(H)2 memory/effector cells that produce inflammatory IL-17 cytokine and promote the exacerbation of chronic allergic asthma. J Exp Med. 2010;207:2479-91.
58. Barczyk A, Pierzchala W, Sozanska E. Interleukin-17 in sputum correlates with airway hyperresponsiveness to methacholine. Respir Med. 2003;97:726-33.

59. Doe C, Bafadhel M, Siddiqui S, Desai D, Mistry V, Rugman P, McCormick M, Woods J, May R, Sleeman MA, et al. Expression of the Thelper 17-associated cytokines IL-17A and IL-17F in asthma and COPD. Chest. 2010;138:1140-7.

60. Agusti A, Edwards LD, Rennard SI, MacNee W, Tal-Singer R, Miller BE, Vestbo J, Lomas DA, Calverley PM, Wouters E, et al. Persistent systemic inflammation is associated with poor clinical outcomes in COPD: a novel phenotype. PLoS ONE. 2012;7:e37483.

\section{Publisher's Note}

Springer Nature remains neutral with regard to jurisdictional claims in published maps and institutional affiliations.
Ready to submit your research? Choose BMC and benefit from:

- fast, convenient online submission

- thorough peer review by experienced researchers in your field

- rapid publication on acceptance

- support for research data, including large and complex data types

- gold Open Access which fosters wider collaboration and increased citations

- maximum visibility for your research: over $100 \mathrm{M}$ website views per year

At BMC, research is always in progress.

Learn more biomedcentral.com/submissions 